\title{
Transformation of kinetic energy to electrical energy through a static system to recharge electronic devices
}

\section{Transformación de energía cinética a energía eléctrica a través de un sistema estático para recargar aparatos electrónicos}

\author{
PRADO-SALAZAR, María del Rosario†, BARBOZA-BRIONES, José Gabriel and ÁVALOS- \\ SÁNCHEZ, Tomás
}

Universidad Tecnológica de Jalisco, Calle Luis J. Jiménez No. 577, $1^{\circ}$ de Mayo , 44979 Guadalajara Jal

ID $1^{\text {st }}$ Author: María del Rosario, Prado-Salazar / ORC ID: 0000-0002-6366-1944 y CVU CONACYT ID: 100541

ID $1^{\text {st }}$ Coauthor: José Gabriel, Barboza-Briones / ORC ID: 0000-0002-3268-6065, CVU CONACYT ID: 457555

DOI: $10.35429 / J R D \cdot 2019.16 .5 .7 .11$

Received July 27, 2019; Accepted November 19, 2019

\begin{abstract}
This project aims to produce electricity using a static bicycle, which has been made some modifications to take advantage of both tires. Along with these have been placed two dynamos which, having friction with the tires, transform mechanical energy into electrical energy, enough to recharge a cell phone. Parallel to this, it stops consuming electricity from the supply network which represents an energy and economic savings, if it is taken to large numbers of cell phones. By using this type of alternative power generation, we are also not emitting greenhouse gases into the atmosphere, which is also helping our health and the environment. This research is able to provide electrical power to cell phones in a friendly way with the environment, entertaining and healthy to keep in shape when charging our electronic devices, being a center of attention for students, since the circuit system allows to deliver $5 \mathrm{~V}$ and $0.7 \mathrm{~A}$ in direct current in approximately 15 minutes, achieving the load of $15 \%$ of a cell battery
\end{abstract}

Renewable energy, Electric generator, Kinetic energy

\section{Resumen}

Este proyecto tiene como objetivo producir energía eléctrica utilizando una bicicleta estática, a la cual se le han realizado unas modificaciones para poder aprovechar ambas llantas. Junto a estas han sido colocados dinamos los cuales, al tener rozamiento con las llantas, transforman la energía mecánica en energía eléctrica, suficiente para poder recargar un teléfono celular. Paralelo a esto, se deja de consumir energía eléctrica de la red de suministro lo cual representa un ahorro energético y económico, si es llevado a grandes cantidades de celulares. Al utilizar este tipo de generación de energía alterna, también estamos dejando de emitir a la atmósfera gases de efecto invernadero, lo cual es también ayuda a nuestra salud y medio ambiente. Esta investigación es capaz de proporcionar energía eléctrica a teléfonos celulares de una forma amigable con el medio ambiente, entretenida y saludable al mantenernos en forma al cargar nuestros aparatos electrónicos, siendo un centro de atención para los alumnos, ya que el sistema circuito permite entregar 5 $\mathrm{V}$ y 0.7 A en corriente continua aproximadamente en 15 minutos, logrando la carga del $15 \%$ de una batería celular.

Energía renovable, Generador eléctrico, Energía cinétic

Citation: PRADO-SALAZAR, María del Rosario, BARBOZA-BRIONES, José Gabriel and ÁVALOS-SÁNCHEZ, Tomás. Transformation of kinetic energy to electrical energy through a static system to recharge electronic devices. Journal of Research and Development. 2019 5-16: 7-11

$\dagger$ Researcher contributing as first author. 


\section{Introduction}

The incessant search for new ways of generating clean electricity on the planet is one of the many objectives that humanity and specifically the scientific society has in order to find in the short and medium term. The purpose of this exploration of clean sources is to reduce dependence on non-renewable sources, such as mainly the burning of fossil fuels, which contribute greatly to global warming and climate change.

This project describes a prototype to transform kinetic energy into electricity by using an exercise bike. The transformed electrical energy can be used to recharge electronic devices for example cell phones, tablets, and some other low-power gadgets.

This alternative allows to stop using the electricity supply network, intrinsically reducing the emission of greenhouse gases, in addition to promoting the physical activity of those who use the prototype.

Said static equipment allows to take advantage of the energy produced by our pedalling which, by installing a pair of dynamos on both tires of the bicycle, will generate twice as much electrical energy compared to singledynamo systems.

\section{Background}

Since the middle of the last century and what we have taken from the current one, the search for clean alternatives for the generation of electric energy that are equally cheaper and more accessible to society, has been an important part of the agenda of countries, industry, and humanity To mention any and to be the subject of our research, there is already the generation of electric energy through the use of kinetic energy through a common instrument, such as the bicycle.

In rural communities in Central America and southern Mexico, they use the bicycle to extract water from the subsoil. This was carried out through the support of the Ministry of Environment and Natural Resources (SEMARNAT) and the Mexican Institute of Water Technology (IMTA) who provided the supplies and installation manuals to the communities.
In Guatemala, the Mayan Pedal Foundation together with the then Mechanical Engineering intern, Jon Leary, implemented an irrigation system by installing several bicycles, which were pedalled by the same people in the community.

This "technology" really improved the daily lives of the locals, without the need to resort to expensive electrical devices or mechanisms that harm the environment (Mayan Pedal, 2010).

Students of Mechatronics Engineering at the National Autonomous University of Mexico (UNAM), Abraham Carmona, Andrés Ortega and Abraham Sánchez, developed as part of their degree project a sustainable design which proved to be very practical for those who used it.

The purpose of its design was to generate electricity that could be used to recharge a cell phone. The result was that they could load such equipment and have a surplus which was used to turn on the bicycle's LED lights. The main disadvantage was that the electrical equipment, being a bicycle that fulfilled its main function of mobility, were exposed in a city where the crime rate is very high.

In Córdoba, Argentina, D`Agostino implemented within a sports club, especially in the area of indoor cycling, a system to take advantage of the potential energy generated there by constant pedalling. He showed that by using installed capacity and replacing old electronic equipment with more energy efficient ones, the club could reduce its electricity consumption by $39 \%$.

As a final background, the work carried out by students of Environmental Technology Engineering of the Technological University of Jalisco, Pablo Álvarez, Mirlo Jiménez \& Sara Arellano, who presented the project "Pedal your Energy" which consisted of the implementation of a bicycle static by placing a dynamo on the rear tire, obtaining an average load production of $15 \%$ over a period of 15 minutes.

\section{Problem Statement}

Talking about climate change has become a topic of day-to-day conversation, not only in research centres, governments or international organizations, but also in the general population. 
Apart from this serious problem, the causes that cause it are analysed and one of these reasons is largely the emissions to the atmosphere generated by the burning of fuels only for the production of electrical energy. This phenomenon can originate naturally, however, anthropogenic pollution accelerates these instabilities in the climate through the phenomenon of the greenhouse effect, which gradually intensifies the temperatures in the atmosphere, bringing with it natural disasters never seen before. Electricity generation is among the activities that emit the most emissions into the atmosphere along with deforestation, the use of motorized transport and the generation of waste. The main resource used to produce electricity has been the use of non-renewable resources such as fossil fuels. Nuclear power and hydraulics have been an important part in the generation of electricity. Currently, other forms of clean generation are being added, such as the use of renewable natural resources such as solar energy and wind energy.

\section{Overall objective}

Transform kinetic energy to electrical energy to recharge electronic devices by using an exercise bike installed in the Workshop of Applied Chemistry of the Technological University of Jalisco.

\section{Justification}

The search for new and innovative technologies is a challenge that every scientist and engineer is willing to accept. We see that every day countless machines, artefacts and products are being produced that come to solve health problems, processes, food, etc. However, very rarely hear of innovative proposals that come to solve specific problems in environmental matters.

The possibility of being able to resume the "Pedal your energy" project will allow us to generate a new bicycle prototype with a mirror system that seeks to produce twice as much electrical energy as what was produced with the original system. If successful, it will be an opportunity to be able to implement within our university campus, which has within its environmental objectives, reduce the consumption of electric energy, in addition to which the student community can be made aware by observing that there are other alternatives to produce your own electric power.

\section{Methodology}

The first stage of this project was dedicated to conducting an investigation of the state of the art, to determine its viability. During the investigation several references were found on electric power generating bicycles, however, none of them showed an identical system.

In the second stage, the pertinent modifications to the "Pedal your energy" prototype were carried out (figure 1). The transformation consisted of incorporating a tire in the front where a second dynamo was installed.

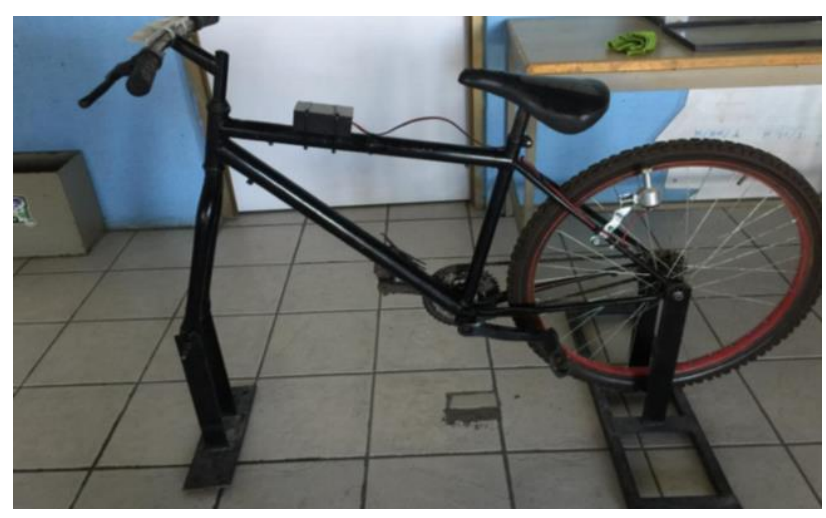

Figure 1 "Pedal your energy" prototype

The part of the levers was also modified by changing the single star to a triple star, which is used in bicycles with changes. This in order to place a chain that is connected to the front tire (figure 2). This modification allows that with the same pedalling that drives the rear tire, drive the front tire in the same way.

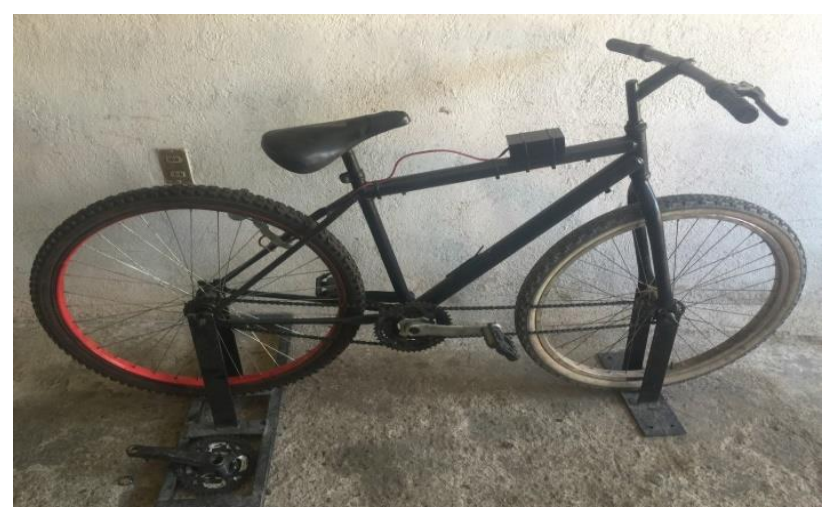

Figure 2 Modified Final Prototype

With the two dynamos installed on both tires, a greater potential will be obtained, with reference to what only one generates. Both are connected to a card that allows you to convert alternating current into direct current, which has a pair of USB inputs, which allow you to connect electronic devices.

PRADO-SALAZAR, María del Rosario, BARBOZA-BRIONES, José Gabriel and ÁVALOS-SÁNCHEZ, Tomás. Transformation of kinetic energy to electrical energy through a static system to recharge electronic devices. Journal of Research and Development. 2019 
The last stage was to perform the functional tests of the prototype. Five tests were carried out on different days in triplicate, placing the same downloaded cell phone (IPhone 6 plus).

\section{Results}

For the realization of the tests, the support of students of the Chemistry Department of Environmental Technology area was requested in order to be able to appreciate differences between the amount of percentage of load produced and the weight of the participant, since as mentioned previously, the load potential will depend on the mass and speed with which the person pedalled.

\begin{tabular}{|l|r|r|}
\hline \multicolumn{1}{|c}{ Competitor } & Time (min) & \% Load \\
\hline A & $20: 06$ & 20 \\
\hline B & $17: 15$ & 16 \\
\hline C & $19: 55$ & 20 \\
\hline D & $13: 09$ & 11 \\
\hline E & $10: 19$ & 10 \\
\hline
\end{tabular}

Table 1 Power generation for a single cell

Table 1 shows the data obtained in the pedalling tests. Participants $\mathrm{A}$ and $\mathrm{C}$ are of the masculine gender of robust complexion and have a more advanced physical condition, they pedalled harder for longer compared to participants $\mathrm{B}, \mathrm{D}$ and $\mathrm{E}$ who are women who have a thin complexion and less condition. According to the information presented in table No. 1 we can determine that the pedalling time is directly proportional to the load generated.

A second experiment was carried out where two electronic devices were connected at the same time, for loading, the data generated is presented in table 2 .

\begin{tabular}{|c|c|c|c|}
\hline Competitor & Weather & $\begin{array}{c}\% \\
\text { Cellular } \\
\text { Load } 1\end{array}$ & $\begin{array}{c}\% \\
\text { Cellular } \\
\text { Load } 2\end{array}$ \\
\hline A & $15: 05$ & 16 & 15 \\
\hline $\mathrm{C}$ & $14: 35$ & 17 & 16 \\
\hline
\end{tabular}

Table 2 Power generation for two cell phones

In this case, only the participants with the best physical condition, and of the male gender, were considered, obtaining as a result that if it is possible to charge two cell phones at the same time, with a similar percentage of charge.

\section{Greenhouse Gas Emissions to the atmosphere}

According to FORBES data, a full-load cell phone consumes $9.5 \mathrm{X} 10-3 \mathrm{~kW} / \mathrm{h}(3.46 \mathrm{~kW} / \mathrm{h}$ per year) (Takahashi, 2017). The averages obtained in both prototypes allow us to give up the supply network at $1.4345 \mathrm{X} 10-3 \mathrm{~kW} / \mathrm{h}(.524$ $\mathrm{kW} / \mathrm{h}$ per year) by pedalling an average quarter of an hour per day.

Using the Emissions Calculator for the National Emissions Registry (RENE) of the SEMARNAT, a total of .304 tCO2e per year would cease to be emitted into the atmosphere. This value may seem minimal, however, when multiplying by the 64.7 million cell phones that existed in Mexico in 2017, the amount of nonemitted emissions would be 19.6 million tCO2e per year.

\section{Conclusions}

Once the tests and data collection of both prototypes were carried out, it was observed that, since there was no storage system, there was a loss of energy, at the time of pedalling.

However, two cell phones were connected at the same time for charging. This is how it can be affirmed that the initial hypothesis is proven, because, if twice the energy is being produced in the same period of time, only that it is not properly channelled to a single electronic device but is distributed in Two equal parts. This final check allows us to observe that trying to channel a third device would give us a failed result because we would incur the initial situation where the result was loss of energy and not gain. It is worth mentioning that during the modifications to the "Pedal your energy" prototype, it was always prioritized to use reusable parts of other bicycles so that the production cost was as low as possible. However, the realization of the prototype with new parts in its entirety would have a high cost, and the benefit would be relatively low, this because the cost of $\mathrm{KW} / \mathrm{h}$ is low.

\section{Proposals}

As mentioned previously, the main objective was to channel the transformed energy to a single point, which was not achieved because a previous storage system was required. This implementation might be able to charge a faster phone always depending on the time and energy generated.

PRADO-SALAZAR, María del Rosario, BARBOZA-BRIONES, José Gabriel and ÁVALOS-SÁNCHEZ, Tomás. Transformation of kinetic energy to electrical energy through a static system to recharge electronic devices. Journal of Research and Development. 2019 
Similarly, it is proposed to use a more efficient transformer than dynamos, which could be an alternator, as long as you are aware that the cost will be higher, and the performance may be less profitable.

Finally, the system used was unique and the benefit relatively little, however, this project can be applied together, where the energy is channelled to a superior storage system that allows it to be used in other areas such as lighting, electricity supply, etc.

\section{Acknowledgement}

The present work was carried out in the facilities of the Technological University of Jalisco receiving the support of the same and of the Academic Body UTJAL-CA-8 for its accomplishment for which we send our thanks

\section{References}

Agudelo Vélez, F., \& García Alegrías, A. (2016). Sistemas de microgeneración de energía a través del ejercicio humano. Santiago de Cali: N.D.

Arellano Arreola, S., Jiménez, M., \& Álvarez González, C. (2015). Transformación de energía mecánica a energía electrica para la carga de teléfonos móviles. Guadalajara.

Barbero, A. (2003). electromagnética. España: Universidad de Castilla.

Brown, L. (2004). Plan B 3.0. Movilizarse para salvar la civilización. Bogotá: Del Bosque.

Caballero, M., Lozano, S., \& Ortega, B. (2007). Efecto invernadero, calentamiento global y cambio climático: Una perspectiva desde las ciencias de la tierra. Revista Digital Universitaria, 1-12.

Carmona, A., Ortega, A., \& Sánchez, A. (2012). Generación de energía eléctrica por pedaleo. Distrito Federal, México: U.N.A.M.

DÁgostino, A. (2014). Diseño de producto: Generación de Energía Eléctrica a partir de bicicletas fijas de Indoor. Córdoba: N.D.

Instituto Mexicano de Tecnología del Agua. (2008). Bicibomba: Manual de instalación. Morelos: Mogaliz.
Macas Ruíz, E. (2017). Definición y estado del arte de la ingeniería concurrente: La manufactura por computer y la mecatrónica. INNOVA Reserch Journal, 44-60.

Mayan Pedal. (2010). Mayan Pedal. Obtenido de http://www.mayapedal.org/Bicibomba_Movil_e ng.pdf

Mecinas Contreras, O., \& Rosas Martínez, G. (2007). Conservación de la energía mecánica. En M. Huesca del Río, \& J. López Estrada, Física Moderna I. México: Colegio de Bachilleres.

Navarro, P., Rui-Wamba, J., Fernández, A., García, C., Juliá, J., \& Rui-Wamba, M. (2010). La ingeniería de la bicicleta. Madrid: Fundación Esteyco.

Panel Intergubernamental de Expertos sobre Cambio Climático. (2007). Cuarto Informe Cambio Climático. Ginebra: IPCC.

Ramos Gutiérrez, L., \& Montenegro-Fregoso, M. (2012). La generación de energía electrica en México. Tecnología y ciencias del agua, 197211.

Rodríguez Becerra, M., \& Mance, H. (2009). Cambio climático; lo que está en juego. Bogotá: Dupligráficas.

Secretaría de Energía. (2018). Reporte de avance de energías limpias: Primer trimestre 2018. México: Secretaria de Energía.

SEMARNAT. (2009). Cambio climático. Ciencia, evidencia y acciones. México: SEMARNAT.

Takahashi, H. (5 de marzo de 2017). FORBES. Obtenido de https://www.forbes.com.mx/cuanto-pagascargar-celular/

${ }^{1}$ Dato obtenido del Instituto Federal de Comunicaciones (IFT) http://www.ift.org.mx/comunicacion-ymedios/comunicados-ift/es/en-mexico-713millones-de-usuarios-de-internet-y-174millones-de-hogares-con-conexion-esteservicio 